\title{
Naval Military Operations in Bonny during the Nigerian Civil War 1967-1970
}

\author{
Chukwuma C. C. Osakwe, Lawrence Okechukwu Udeagbala \\ Department of History and International Studies, NDA, Kaduna, Nigeria \\ Email: lecturec@yahoo.com \\ Received 18 May 2015; accepted 27 June 2015; published 30 June 2015 \\ Copyright (C) 2015 by authors and Scientific Research Publishing Inc. \\ This work is licensed under the Creative Commons Attribution International License (CC BY). \\ http://creativecommons.org/licenses/by/4.0/ \\ (c) (7) Open Access
}

\begin{abstract}
The importance and role of the Navy in the Nigerian Civil War, 1967-1970 have not attracted any scholarly attention in the burgeoning scholarship of the civil war. This study is an attempt at introducing the navy in the discourse of the war. More importantly, they not only made strides in our knowledge of naval warfare but also played a significant role in the outcome of the war.
\end{abstract}

\section{Keywords}

Biafra, Bonny, Civil-War, Navy, Nigeria, Nigerian Civil War

\section{Introduction}

The maintenance of the territorial integrity of Nigeria is one of the key responsibilities of the Nigerian Armed Forces and it is enshrined in the Nigerian constitution (Constitution of the Federal Republic of Nigeria, 1999). Between 1967 and 1970 the Armed Forces of Nigeria which comprised the Army, Navy and the Air Force were able to discharge that constitutional responsibility by maintaining the indivisibility of the country. By 1967 however, the Nigerian navy was only about eleven years old having been formally established in 1956 (The Making of the Nigerian Navy, 2004). Meanwhile, the Nigerian Navy could be said to become fully operational as a modern navy in 1964 when the naval act of that year obviated all the encumbrances imposed on the navy by the 1956 naval act (Asoluka, 2003). Howbeit, despite the seemingly "inexperience" of the navy in warfare considering its age, at least, when compared with the army which began its metamorphosis as a force since 1863 (Nigerian Army Education Corps and School, 1992), the performance of the Nigerian navy during the civil war was vital to the victory of the Federal Military Government in the war.

\section{The Navy and Preparation for Military Action against Biafra}

The Nigerian civil war officially begun on the 6th of July 1967, but for the Nigerian Navy, the war started in 
May 1967 when the Federal Military Government imposed economic sanctions by way of a littoral blockade on Eastern Region (Biafra) and the navy was charged with the responsibility of implementing the sanctions on the Atlantic coast. While the navy was technically the first arm of the force that was charged for a show down against Biafra, when the shooting war came in July, the navy appeared to be less prepared for the military action. This was not due to unwillingness of the navy but to the fact that Easterners in the navy and their sympathizers carried out some sabotage on the ships of the Nigerian navy especially NNS Nigeria before they departed to Biafra which put on hold some initial action expected of the Nigerian navy. For instance, despite the tightened up of security at the naval shipyard in Lagos, on Saturday 22 April 1967, the base was placed in darkness at about 2000 hours for unknown reasons by unknown people. It took about two and half hours before power was restored but on Monday, 24th April, to the chagrin of the officers of the navy, all sensitive and electronic equipment in almost all the ships had been vandalized and the armament in the Flagship, NNS Nigeria had been rendered useless (Soroh, 2001: pp. 224-225). In fact, navigational aids, gunfire pins, communication sets and rather engine parts either disappeared totally or were badly damaged (Adekunle, 2004: p. 93). As if that was not bad enough, since the crisis that led to the war started, the navy gradually began to lose its members who were clandestinely moving to the East. Although unlike in the army where it was alleged that some of the officers and men of the force of Eastern Nigerian origin were killed by their comrades, not even a single officer of Eastern Nigeria origin was killed in the navy before the shooting war started ${ }^{1}$. But members of the navy who were Easterners kept on disappearing from the naval base in Lagos to Eastern Nigeria. On 24th April 1967, it was announced that 30 ratings of Eastern origin absconded from duty. In other to make it easy for the navy to monitor them, all Igbo officers and ratings were drafted to NNS Beecroft (Soroh, 2001: p. 224). In other words, when the shooting war came, the navy did not only lack the manpower to prosecute the war, it also lacked material resources to wage the war against Biafra.

Despite the sabotage, within a short period, the navy was able to replace everything that was damaged by the "fleeing Biafrans". According to Col Adekunle, "due to the excellent relationship between the Navy personnel and their foreign suppliers, the navy was able to replenish her stock and in a very short time" (Adekunle, 2004: p. 93). To make sure that secrets of the navy was effectively hidden from the Biafrans and to shock the Biafrans who might have erroneously believed that the Nigerian navy had been immobilized at least for the time being for any possible military action against the east, everything about the restoration of the damaged items were shrouded in secrecy. It was further decided that troops would sail from Lagos under the cover of darkness and that assault would be carried out at dawn. Other measures taken were to dismiss all non-essential civilians from Ikeja cantonment, strict censorship of mail and tapping of all telephone calls, and random roll calls to flush out intruders in the cantonment (Adekunle, 2004: p. 93).

In addition, joint military training was carried out by the army and the Navy at Taqua Bay in Lagos to prepare the two forces for a coordinated action against Biafra. This gave the two services some good experience and e spirit de corps. To further enhance confidence between Naval and Army officers, a series of joint mass dinners were organized. Naval maneuvers on the high sea of Lagos drove home the lessons of ship pitching, embarkation and disembarkation in daylight and darkness etc. (Adekunle, 2004: p. 91-103). The Army was also trained in handling dinghies and outboard engines because they needed boats for moving their men in the creeks as soon as they were put ashore by the naval ships (Soroh, 2001: p. 228). It is important to note that the joint military training was particularly important because the Southern sector of the war held the key for winning the war on the Federal side and even for the Biafrans. This is because of the heavy presence of oil installations in the area which both governments badly needed to be in total control so as to raise money for the prosecution of the war. So the Nigerian defence headquarters did not want to experience any mistake on the southern sector because of the colossal damage the mistake might cause to the Federal sides hope of gaining ascendancy over Biafra in the war.

With the replacement of the damaged items in the naval ships and the joint military training with the army, the navy was thus ready for the military action against the East especially the control of the water ways of the Atlantic coast so as to enforce the economic blockade imposed on Biafra by the Federal Military Government.

\section{The Navy and the Military Action in Bonny}

The military action in Bonny sector of the Nigerian civil war was a different type of warfare from those waged

${ }^{1}$ Interview with Michael Adelanwa, Vice Admiral, 78+, Lagos, 01/04/2014. 
by the First, Second and Third Marine Commando Divisions of the Federal army. The Nigerian navy was ordered to implement the blockade against Biafra on the Atlantic coast long before 3rd of July 1967 when the Supreme Military Council ordered the military action against Biafra which eventually commenced on 6th of July $1967^{2}$. Along with the soldiers of the Third Marine Commando Division (3MCDO) the navy was the last force that got involved in the shooting war against Biafra. Therefore, the military operation in Bonny was a combined operation between the army of the $3 \mathrm{MCDO}$ and the Nigerian navy against the Biafran army and the Biafran navy.

The navy and the soldiers of the 3MCDO amphibiously landed in Bonny on the 25th of July 1967 to the surprise of the Biafran armed forces. Because the Biafran military authority probably due to the sabotage on the ships of the Nigerian navy, among other reasons, inconsiderately supposed that the Nigerian navy was quite incompetent or rather incapable of carrying out amphibious operations on Biafra. The secessionist Biafran leader, Colonel Ojukwu's conversation with the British Deputy High Commissioner and his American counterpart in Enugu gave credence to the above Biafran unpreparedness. In their interaction, James Parker, the U. K Deputy High Commissioner in Enugu and Bob Bernard his American counterpart asked him his view on the rumored Federal invasion from the sea, Ojukwu simply laughed. He laughed as he could not comprehend the Nigerian navy to be equipped with the capability to enforce a blockade of Biafran ports or amount amphibious operation on Biafran coasts with its winding creeks and primordial mangrove swamp running approximately 20 miles inland. He therefore replied that "he doesn't know where the Nigerian naval vessels go when they depart Lagos, but they are not, he repeated, they are not patrolling off the coast of Biafra" ${ }^{3}$.

Colonel Ojukwu's optimism notwithstanding, when the navy and her 3MCDO counterparts were ready for the military action against Biafra nothing stopped them from doing so. Thus, on 24th July 1967, all the ships taking part in the military operation had rendevoused with the flagship, NNS Nigeria in Lagos (Soroh, 2001: pp. 228229). On July 25 , however, by 0400 hours, all the ships had taken positions in the pre-designated battle ground. The suspected Biafran positions were effectively cannonaded by the Nigerian navy especially NNS Nigeria commanded by Captain Nelson Soroh seconded by Commander Michael Adelanwa and NNS Ogoja commanded by Lt.Cdr. Akin Aduwo. It was after the heavy bombardment of the Biafran positions that NNS Lokoja the landing craft began to land the soldiers on the beach. The beach that was chosen for the deployment of soldiers was at the northern part of the Bonny Island for two important reasons. One was that the intelligence report revealed that concentration of the Biafran forces there was highly infinitesimal but one other major reason for choosing the northern part was to deny the Biafrans of possible reinforcement from Port Harcourt ${ }^{4}$. However despite the successful landing of troops by Lt. Cdr. Joe, his ship NNS Lokoja would have been the first casualty of the war if Biafra had had a formidable force in that sector or rather if the naval preliminary bombardment of the landing site was not effective to disorganize the few but ebullient Biafran soldiers in the town. This was because NNS Lokoja after the first landing was grounded and could not take reinforcements to the town. However Peterside beach, which was opposite Bonny, was conveniently captured by the landing party who landed in rubber dinghies and small crafts (Soroh, 2001: p. 231).

In wars, amphibious operations is vital in taken the enemy in areas they least expect or areas where imagined assault from an opponent is impossible. Nevertheless, the preliminary naval bombardment was very effective. It was able to dislodge the Biafran naval ratings stationed in Bonnny and made them to put little or no resistance to the landing party. Without the bombardment and the successful landing of the foot soldiers in the areas they could operate, the Biafran government would have continued to control the oil installations in Bonny and would have had the finance to prosecute the war. NNS Ogoja commanded by Lt. Cdr. Akin Aduwo with Lt. Denson Okujagu as his second-in-command and Sub. Lt. Johnson Adisi as engineer was the ship that led the naval fleet in military operations to storm Biafra from the sea. It is important to note that NNS Ogoja was a twenty year old American Patrol Corvette whose fatigued engine was revived by Lt. Adisi who was called back to service primarily for that purpose, having been compulsorily retired from the navy as a result of a manner considered not befitting of an officer 5 .

Apart from NNS Ibadan (later renamed BNS Ibadan) which was on Eastern patrol under an Igbo officer Lt. Cdr. P.J Odu, there was no known war ship possessed by the Biafran navy. Every other ship or gunboat used by the Biafran navy was reconstructed from the boats of Shell B.P inherited by the Biafran navy in Port Harcourt.

\footnotetext{
${ }^{2}$ The News, February, 25, 2013, p. 16.

${ }^{3}$ Demola Awoyokun, "Special Report...file:///ciusers/Hp/destop/economic-blockade.htm.

${ }^{4}$ Interview with Akin Aduwo, 75, Retired Chief of Naval Staff, Lagos, 19/03/2014

${ }^{5}$ Ibid.
} 
In synergy with the Biafran Research and Production Unit, some of the inherited boats were reconstructed to serve military purposes ${ }^{6}$. The NNS Ibadan which was on Eastern patrol duties was deliberately delayed by Odu to return to Lagos when he sensed that the Eastern region might secede from the Federation as the only solution to the already impasse reached by Colonels Ojukwu and Yakubu Gowon of the Nigerian government. Thus, Lt. Cmdr. Odu kept on giving various reasons why the ship could not return to Lagos. When Biafra was declared on 30th May 1967, the Biafran navy inherited the ship and christened it BNS Ibadan?

On 26th July 1967, the Biafran and Nigerian navy had the first showdown in the war. While the Nigerian navy was led by Lt. Cdr. Akin Aduwo, the Commander of NNS Ogoja, the Biafran navy was led by Lt. Cdr. P. J. Odu the commander of BNS Ibadan. Before the navy fleet left Lagos for Bonny, they were advised to maintain eagle eyes on BNS Ibadan which was the only known war vessel possessed by the Biafra navy in the eyes of the Nigerian navy. Its disablement they enthused, would remove the inherent threat posed by the Biafran navy. Prior to the amphibious landings off the Biafran coast by the Nigerian navy, Ojukwu had boasted that he would quite conveniently line the bottom of the creeks with the debris of the Nigerian navy should they menace the coast of Eastern region (Ekpu, 2012).

Sequel to the above, when BNS Ibadan, now flying Biafran flag was sighted sailing along Abomena/Degama channel off Bonny River; it was hotly pursued by NNS Ogoja skippered by Akin Aduwo . The battle that ensued was quite intense. In terms of fire power, BNS Ibadan was better equipped than NNS Ogoja which had a 3-inch gun mounted on it. While the Biafrans mounted puny Bofors anti-aircraft gun on BNS Ibadan. It was designed to pump out 40/60 mm shells in rapid succession. But unfortunately, when she engaged Ogoja, it kept jamming every third or fourth round (Odu, 2009). While BNS Ibadan had advantage in fire power over Ogoja, Ogoja had advantage of operating from an area of the sea that it was impossible for a ship to run aground. It is important to note at this juncture that the commanders of the two ship NNS Ogoja and BNS Ibadan were good friends in the "former Nigerian" navy. Lt. Cdr. Pascal Odu the commander of BNS Ibadan was the first Nigerian Naval communication specialist. He attended British Royal Naval College, Britania. Both him and Lt. Cdr. Aduwo were commissioned about the same period and promoted Lieutenants also at the same period. As Lieutenants, they had to choose their areas of specialization. Odu elected to major in naval navigation while Aduwo opted for communication. But unfortunately Odu could not proceed to be a navigator on account of bad sight and Aduwo had been nominated for communication which would have been his second choice. Meanwhile, in a rare show of loyalty to a friend, Aduwo caused his own nomination to be waived so that Odu could take his place. That was how Odu proceeded to India for a course in naval communication and eventually emerged as the first Nigerian specialist in that area (Omosefunmi \& Akinlonu, 1997).

In the battle that ensued between the two 'former' friends, Aduwo fired barrage of volleys on BNS Ibadan which was equally responded by Odu. In such a desperate situation, Odu had to improvise on the method of firing his guns which was constantly jamming. Consequently, he devised a maneuver whereby he would turn around and steam in the opposite direction whenever the gun jammed to give his crew latitude to clear it and to maintain an optimum firing distance from Ogoja. Then he would turn the ship around and fire on Ogoja but obviously, not all part of river was deep enough to take the ship. By the time he employed this tactics for about two or three times, he drifted out of the channel into shallow waters and the ship ran aground thereby providing a fixed target for Ogoja.

When one of the cannons from Ogoja eventually got Ibadan and set fire in the engine room, Aduwo stopped firing and was ready to save his old friend and his crew. According to him,

when the bullet from Ogoja hit Ibadan and it went up in flames the Captain of the ship, Pascal Odu managed to maneuver his ship to the side of Degema channel and beached his ship while the smoke was billowing out through the funnel on the deck, obviously the ammunition gun on board the ship had been hit and set on fire. He beached his ship and stood up on the bridge and allowed the surviving ratings and officers to jump overboard and disappear. He like a traditional professional Captain of his Ship, was the last human being to leave that ship. I went on the mega phone to appeal to him to join my ship because I saw him clearly through the binocular. I was going to send my life boat to him but he came down the step and disappeared. I was determined to send my life boat to save him and his crews. I was waiting for his signal but unfortunately, he preferred to disappear.

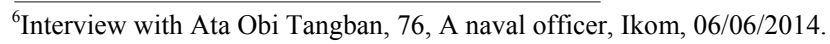

${ }^{7}$ Ibid.

${ }^{8}$ Interview with Akin Aduwo, 75, Retired Chief of Naval Staff, Lagos, 19/03/2014
} 
Aduwo probably was not quite sure that Odu would not come on board. The thick smoke billowing out of the burning ship must have eventually blocked his view and before he could realize what happened, the Biafrans had all gone. If he had known, there was a possibility that he would attempted capturing some prisoners of war who would have made some useful revelations on the positions of the Biafrans.

About six years after the civil war, Odu visited Aduwo at the Western Naval Command, Apapa where they shared their experiences in the Bonny operation. When Aduwo asked him why he refused to come on board when his ship was destroyed, Odu responded:

"Come on Akin, how would you expect me to have come under that circumstance? I heard you loud and clear really, but I just could not come. Any member of your crew could easily have shot me while you are not looking. You can never tell in war time" (Odu, 2009).

Lieutenant Commander Odu's predicament is quite understandable. The gun on his ship became faulty and it put the ship in a disadvantaged situation when she engaged Ogoja whose firing was effective. Howbeit, it could be argued that the further training received by Commanders Aduwo and Odu came into play in the battle ground. Aduwo who was a navigation specialist and was functioning in that capacity during the war was bound to have an edge over his opponent who majored in naval communication but was functioning as a navigator in the war. Odu was not a navigation specialist although he had good knowledge of navigation as a trained naval officer but would not have been to the extent of daring a navigation specialist in battle. He might have become confused and disappointed when the guns on his ship began to malfunction. He probably had little or no professional training to know what to do when the gun jammed other than to be turning the ship around. Aduwo could be said to have proved that the further professional training he received as a navigation specialist was not in vain. Despite the disadvantage Aduwo's Ogoja had in terms of fire power when compared with Odu's Ibadan, Aduwo pressed and effectively utilized the opportunity he had over his opponent by operating from and on a better part of the high sea. Aduwo knew that although Ogoja was not an easy match for Ibadan which had been upgraded by the Biafrans in fire power capacity but at that moment, Ibadan was in trouble (Odu, 2009).

With the liquidation of Biafra's Ibadan and its inherent threat to the Nigerian navy, and the successful landing of the foot soldiers on the selected beaches, Nigerian naval domination of Bonny was complete at least for little while. In fact, the Bonny amphibious operation was so successful and had been adjudged to be the first amphibious landing in Africa by an independent African country after World War $11^{9}$.

\section{Biafra in the Battle of Bonny}

There is no doubt, the Nigerian navy was victorious in the Bonny operation but their victory was for a while as the Biafrans refused to concede Bonny to them. They made series of efforts to retake the town from the Nigerian forces. In one of the encounters, just after NNS Nigeria had brought supplies from Lagos, the Biafrans engaged the naval ships with their home made gunboats and sunk NNS Sapele commanded by Lt. Sereki who eventually became the most senior naval casualty in the war. The battle was so frustrating that not even his body or any member of his crew was recovered. The ship was sunk ${ }^{10}$. One of greatest challenges of the Nigerian navy during the war was the activities of BAF (Biafran Air Force) whose B52 bomber and helicopters constituted a menace to the ships of the Nigerian navy especially the flag ship that could not enter into smaller channels because of its size and therefore at the initial stage (although it later did in some places) was stationed on the open sea where it posed easy target for the Biafran air force. That notwithstanding, the navy was busy patrolling the creeks protecting the oil tanks from Biafran incursions which did not in any way deter the Biafrans. In one of the strafing missions of the BAF, one of the oil tanks was hit by an improvised explosive device locally known as (ogbuniigwe) or derisively as Ojukwu's bucket, which ignited the adjacent tanks. The inferno which was difficult to quench seared for many months ${ }^{11}$.

Meanwhile, this Biafran attempt to retake Bonny, otherwise known as operation Sea Jack, started from September 25, 1967 after the Biafrans successfully opened another theater of the war in the Midwestern region of Nigeria, often referred to as the Midwestern invasion. It would seem that it was the defeat suffered by the Biafran forces in Bonny that compelled the Biafran Military Authority to renege the hitherto agreement with the Federal Government to leave the Midwestern region out of the war. According to Biafran Colonel Achuzia, the

\footnotetext{
${ }^{9}$ Interview with Michael Adelanwa, Vice Admiral, 78+, Lagos, 01/04/2014.

${ }^{10}$ Interview with Akin Aduwo, 75, Retired Chief of Naval Staff, Lagos, 19/03/2014

${ }^{11}$ Ibid.
} 
Biafran invasion of the Midwest was to push Biafra into the offensive militarily and force the Federal army into a defensive position. This, Achuzia maintains, would have brought a situation where the Federal Government would be forced to withdraw the troops menacing Biafra in the North, thereby relieving the pressure facing Enugu, the initial Biafran capital before Umuahia, at the time the offensive was launched. It would also have forced the immediate withdrawal of Federal troops under Lieutenant Colonel Adekunle based on Bonny Island who would be withdrawn to Lagos for the defence of Lagos and the Western Region. It would, furthermore, have removed the presence of the Federal warships which had been carrying out sea blockade on the Bight of Biafra against Biafran shipping (Achuzia, 1986).

The calculation of the Biafran military authority worked to some extent as the soldiers of the 3MCDO division and men of the Nigerian navy operating in Bonny were quickly drafted to Midwestern Region leaving the defence of Bonny in the hands of $7^{\text {th }}$ battalion under the command of Lieutenant Colonel Abubarkar supported by a couple of naval personnel who supplied them with logistics for the prosecution of the war. As soon as Federal forces thinned down in Bonny following the invasion of the Midwest by Biafrans, the Biafrans wasted no time as they cashed in on the weaknesses of the Federal forces in Bonny. The Biafran navy assisted by the Biafran army launched an offensive against the men of the 7th battalion and their naval counterparts in Bonny. The Biafran military authority was pretty sure through intelligence gathering that the Federal Military Government had no other manpower anywhere to defend the town of Bonny which was even the reason for withdrawing the forces already operating in Bonny for the defence of Midwestern region and ostensibly Lagos, the Nigerian Federal government capital. Within a short moment, the Biafran forces nearly whipped out the presence of the Federal forces from the town but the timely intervention of the Nigerian navy saved the situation. When the news of the Biafran onslaught got to naval headquarters in Lagos, NNS Nigeria was ordered back to Bonny. According to Admiral Soroh,

By 0930 hours we arrived Bonny harbor and found that Peterside, the opposite village was on fire. We opened fire immediately at the enemy. A big battle was on between Federal troops and the rebel forces. We found that the enemy was in great strength outnumbering the Federal troops considerably. The second phase of the Bonny operation had began (sic). The Biafrans had landed behind Peterside with a battalion strength or more conveyed to the island in large barges and launches. Federal forces in Peterside were only a company under the command of Captain Bello. Our arrival was in good time. The gunfire from the ship was very effective and the enemy was engaged from the moment we arrived till night. I had sent a message to the authorities in Lagos as soon as we arrived thus: "Arrived Bonny 0930 I am engaging the enemy". The timing of the signal was to convey to the Naval Headquarters and the Admiral the gravity of the situation...And the lucky part of it was that NNS Nigeria was in the area. Some of our men were actually pushed into the water when we arrived (Soroh, 2001: pp. 241-242).

From the information available, effort of the Biafrans to retake Bonny was frustrated by the activities of the Nigerian navy because of the obvious reason that Biafra had no naval answer to activities of the Nigerian navy. As a result, the Biafran authority ignored the army and maintained their intelligence gathering on the ships of the Nigerian navy. Whenever it was revealed to the Biafrans that the number of the naval ships on the water of Boony had reduced, their response was always swift. While all the ships taking part in the war performed wonderfully well, Biafrans appeared to have especially dreaded Lt. Cdr. Aduwo's NNS Ogoja since it had proved itself to be the most effective of the naval fleet fighting Biafra. In fact, it was said that the Biafran intelligence gathering was mostly centered on Ogoja which the Biafrans renamed Hot Iron. Whenever Ogoja left for Lagos for repair or to perform other assignment, the Biafran field intelligence sources would communicate to the Biafra authority that Hot Iron was off. The absence of Ogaoja from Bonny waters was always followed by intense effort by the Biafrans to retake the town. Biafran field intelligence sources were accurate. But whenever they signaled to the Biafrans that Hot Iron was back, they would quickly vanish from the scene because their greatest enemy was back ${ }^{12}$. In fact it appeared that Ogoja was even more powerful than the Flagship NNS Nigeria. This was because Ogoja was a very small vessel that could operate on smaller channels without running aground than NNS Nigeria. NNS Nigeria was like a guardian angel to all the ships and so the navy did not want to risk the ship entering into very small channels for the fear of running aground. If Biafra succeed in destroying NNS Nigeria, it would appear that they have succeeded in destroying the Nigerian navy. So any battle in the small channels was always led by NNS Ogoja which was a smaller vessel. But despite the efforts of the Biafran

\footnotetext{
${ }^{12}$ Interview with Akin Aduwo, 75, Retired Chief of Naval Staff, Lagos, 19/03/2014
} 
Armed forces; they failed to retake Bonny from the hands of the Federal forces. In other words, operation Sea Jack failed to achieve its purpose.

\section{Conclusion}

The Bonny amphibious landing was a combined operation undertaken by soldiers of the Third Marine Commando led by the Nigerian navy. It was the first amphibious landing in Africa by an independent African state. Because of the terrain of Bonny and also because of the sabotage carried by Biafran sympathizers in the Nigerian navy on the naval ships, the Biafran military authority grossly underestimated the competency of the Nigerian navy to blockade Biafra or to amphibiously land on Biafra. Despite the sabotage and other setbacks suffered from the Nigerian navy, it got itself prepared for the war and indeed successfully landed the soldiers of the $3 \mathrm{MCDO}$ on the Biafran beaches and bombarded the Biafrans until the foot soldiers were able to fix their feet on the dry ground. Meanwhile, Biafra was very smart in opening another front in the war which compelled the Federal forces to be thinned down in Bonny in order to defend the Midwestern region. The thinning down of the Federal forces in Bonny enabled the Biafrans to launch a very heavy offensive in Bonny to retake the town but their effort was again thwarted by the Nigerian navy. The activities of the Federal navy contributed immensely to the victory of the Federal government because they secured Bonny and its oil installations, thereby making the Federal government to be in control of the oil installations which was vital to the prosecution of the war.

\section{References}

Achuzia, J. O. G. (1986) Requiem Biafra (pp.62-63). Enugu: Fourth Dimension.

Adekunle, A. (2004) The Nigeria Biafra War Letters A Soldier's Story (pp.91-103). Atlanta: Phoenix.

Asoluka, C. (Ed.) (2003) National Maritime Authority's Compilation of Nigerian Maritime Laws" (Navy Act (CAP.288) (Vol. 2, p. 420). Lagos: El-machi Publishers.

Constitution of the Federal Republic of Nigeria (1999) Constitution of the Federal Republic of Nigeria (p. 85). Lagos: Federal Government Press.

Ekpu, R. (Ed.) (2012) Ojukwu (p. 28). Lagos: Mayfive Media Limited.

Nigerian Army Education Corps and School (1992) History of the Nigerian Army 1863-1992 (p. 11). Nigerian Army Headquarters.

Odu, P. J. (2009) The Future That Vanished a Biafra Story (p. 115). Lagos: Equitable Publishers.

Omosefunmi, F. and Akinlonu, F. F. (1997) 30 Days in Power, 4 Years in Command the Story of Vice Admiral Akin Aduwo (p. 53). Lagos: Advent Communication Limited.

Soroh, N. B. (2001) A Sailor's Dream Autobiography of Rear Admiral Nelson Bossman Soroh. Lagos: Crucible Publishers.

The Making of the Nigerian Navy (2004) A Publication of the Policy and Plans of the Nigerian Navy (p. 10). C \& A Prints Nigeria Limited. 